\title{
METAMORFOSES: O COELHO-HOMEM OU HOMEM-COELHO, DE MURILO RUBIÃO
}

\author{
Luciana Morais da Silva ${ }^{1}$
}

\begin{abstract}
Resumo: Os cenários atravessados pela manifestação do insólito têm se tornado recorrente no âmbito das literaturas do fantástico. A personagem principal em "Teleco, o coelhinho" (RUBIÃO, 2005, p. 143-152) é um ser entre homem e animal. A narrativa pouco a pouco guia seus leitores pelo universo de um coelhinho, frágil ou intrometido? Não se sabe muito bem quais as fronteiras da convivência entre um homem e um coelho, aparentemente, inofensivo. $O$ insólito irrompe dando à narrativa uma exacerbação das ações, com personagens que agem de modo inesperado, mas que no instante seguinte são incapazes de tomar as atitudes esperadas. O coelho que se metamorfoseia em homem, ou que almeja tornar-se um, é o mesmo que desperta a solidariedadedo outro a ponto de acolhê-lo em seu lar. Assim, a narrativa rubiana revela ao seu leitor, com maestria, uma vivência quotidiana, corriqueira, em que as pessoas buscam satisfação, porém com ela se debatem frente ao terror experimentado a partir de seus próprios dia-a-dia.

Palavras-Chave: Insólito ficcional, Personagem, Estrutura narrativa, Metamorfose.
\end{abstract}

Abstract: The scenarios traversed by the manifestation of the uncommonhas become the recurrent in the literatures of the fantastic. The main character in "Teleco, o coelhinho" (RUBIÃO, 2005, p. 143-152) is a being between man and animal. The narrative slowly guides its readers through the universe of a bunny, fragile or nosy? No one is quite sure about the boundaries of coexistence between a man and a rabbit apparently harmless. The uncommon breaks out giving the narrative an exacerbation of the actions, with characters who act in unexpected ways, but in the next moment are unable to make the expected attitudes. The rabbit is metamorphosed into a man, or who aspires to become one, is the same that awakens solidarity in another about to receive him into his home. Thus, ruabiana narrative reveals to its

${ }^{1}$ Mestre em Letras pela Universidade do Estado do Rio de Janeiro (UERJ) e Mestre em Letras Vernáculas pela Universidade Federal do Rio de Janeiro UFRJ); doutoranda do Programa de Pós-Graduação em Letras, Literatura Comparada da UERJ, sob a orientação do professor Dr. Flavio García, estando vinculada ao projeto de pesquisa "O insólito fic- cional nas narrativas curtas e de média extensão de Mia Couto: o recurso a estratégias de construção narrativa realista-maravilhosas como vertente possível da literatura con- trahegemônica moçambicana" desde 2010, e ao grupo de pesquisa "Nós_do_Insólito: vertentes da ficção, da teoria e da crítica" desde a sua fundação. Endereço eletrônico: luciana.silva.235@gmail.com. 
reader, with mastery, an everyday experience, commonplace, where people seek satisfaction, but it struggles the reader against the horror experienced from their own day-to-day.

Keywords: Ficcional uncommon, Character, Narrative structure, Metamorphosis.

\section{INTRODUÇÃO}

A construção insólita do escritor brasileiro Murilo Rubião percorre as estradas do fantástico, dialogando com imagens já há muito conhecidas, principalmente ao apresentar aos seus leitores o espaço citadino em diálogo com a metamorfose. Como pode a transformação do corpo desestruturar toda uma vida? Em “Teleco, o coelhinho" (RUBIÃO, 2005, p. 143-152) não há desestrutura, mas reestrutura, já que o pobre metamorfoseado consegue abrigar-se na casa de outrem. Entretanto, o tempo da acolhida é também incomum, inaudito, com encontros e desencontros devido ao inconformismo entre os desejos das personagens.

O fantástico em seu sentido mais amplo, lato sensu, denota aqui o sentido de uma manifestação insólita desestruturada e desestruturante, marcada pela involuntária adequação dos tempos e sentidos, com personagens nefastamente envolvidas pelo horror do quotidiano, como é o caso de Teleco, que deseja ser homem, ainda que desconhecendo os custos de sê- lo.

O escritor, nascido em Carmo de Minas - com centenário a ocorrer em 2016 por ocasião de seu aniversário -,constrói sua narrativa a partir de um olhar para uma cena quotidiana, duas pessoas olhando o mar, porém o outro da narrativa não é o humano esperado, mas um coelho capaz de metamorfoses, demonstrando o teor inesperado da construção. Assim, as personagens rubianas dialogam como seres munidos de humana aparência, como em fábulas, mas confrontadas pela convivência. O estranhamento principal da narrativa ocorre a partir das próprias personagens, que a princípio nada denunciam, apenas incomodam-se quando desejam a mesma mulher, um sendo homem e o outro metamorfoseado.

\section{INTERSECÇÕES INSÓLITAS}

Quando certa manhã Gregor Samsa acordou de sonhos intranquilos, encontrou-se em sua cama metamorfoseado num inseto monstruoso. Estava deita- 
do sobre suas costas duras como couraça e, ao levantar um pouco a cabeça, viu seu ventre abaulado, marrom [...]

- O que aconteceu comigo? - pensou.

Não era um sonho. Seu quarto, um autêntico quarto humano, só que um pouco pequeno demais, permanecia calmo entre as quatro paredes bem co-nhecidas (KAFKA, 1997, p. 7).

A transformação experimentada por Gregor, personagem de Kafka em A metamorfose,ultrapassa os limites humanos, com sentidos dispersos e corpo avantajado, a personagem deixa de conviver no âmbito da racionalidade para ascender ao da naturalização. De mesmo modo, as persona-gens, de várias narrativas do escritor brasileiro Murilo Rubião, confrontam- se com a realidade ao excederem os limites entre o sólito e o insólito.

As minuciosas descrições da personagem kafkiana tornam o terror de sua condição uma fronteira em suas próprias relações pessoais, pois a repulsa e mesmo receio não deixavam que ele nem mesmo mantivesse diálogos com seus parentes. O insólito, como aquilo que rompe com o esperado, com a ordem natural dos eventos, é, nessa narrativa, elemento propulsor, principalmente pela metamorfose ocorrida com o jovem protagonista.

A transformação insólita de Gregor, a ideia da metamorfose e de suas nuances até mesmo malignas, revela a insolubilidade da constituição da personagem rubiana Barbosa, em "Teleco, o coelhinho", que, em sentido diverso, é também vítima da metamorfose. Ao contrário da metamorfose de Gregor, de homem em inseto, Teleco almeja ser homem, chegando a afirmar sua condição humana, ainda que descrito pelo narrador como um canguru, na maioria do tempo.

O mundo em torno da personagem rubiana parece normal, quotidiano, porém repentinamente esbarrar ou trocar palavras com um coelho não seria algo ordinário ou mesmo esperado, a partir do tido como lógico pelo senso-comum. Como se pode perceber desde o início do conto de Rubião o insólito compõe o quotidiano, o coelho falante é parte da realidade. David Roas (2011, p. 150), ao discutir sobre narrativas que, invertendo o sentido mais corriqueiro do fantástico, se constroem sob a ausência de vacilação diante do insólito, revela: "Pensemos ahora en el efecto que causan en el receptor tales escenas y por qué. Ambas, no lo olvidemos, se desarrollan en espacios que el receptor reconoce como semejantes al mundo extratextual".

Os estudos sobre o fantástico alcançaram na contemporaneidade expressão evidente e, nesse sentido, gerou uma amplitude de análises e pro- 
dução ficcional. Entretanto, não se pode esquecer o percurso todoroviano sobre a formação e consolidação da narrativa fantástica, que, na presente discussão, aborda também a reviravolta dos estudos literários do século XX, tendo como marco $A$ metamorfose, de Kafka. A narrativa mencionada tem como fundamento a manifestação do insólito, em que um homem transforma-se em inseto, de modo inexplicável e não questionado. De mesma forma, na narrativa rubiana, o coelho age desde o início como um humano, permitindo que se lembre da fábula, a não ser pelo pedido do coelho, que diz: “- Moço, me dá um cigarro?” (RUBIÃO, 2005, p.143).

A solicitação da personagem é inesperada, mas o narrador não questiona o evento insólito, como outrora ocorria nos textos fantásticos. Assim, como destaca Italo Calvino, "Sentimos que o fantástico diz coisas que se referem diretamente a nós, embora estejamos menos dispostos do que os leitores do século passado a nós deixarmos surpreender por aparições e fantasmagorias, ou melhor, estamos prontos a apreciá-las de outro modo" (2004, p. 9). A construção da narrativa guia o leitor para uma percepção diversa, convidando-o para jogar o jogo, e como afirma Eco (1994, p. 89):

temos de admitir que, para nos impressionar, nos perturbar, nos assustar ou nos comover até com o mais impossível dos mundos, contamos com nossos conhecimento do mundo real. Em outras palavras, precisamos adotar o mundo real como pano de fundo.

Isso significa que os mundos ficcionais são parasitas do mundo real.

O jogo insólito enunciado pelo pedido do coelho é atestado pelo narrador, que, ao invés de medo ou estranhamento, nada demonstra, achando mesmo que se tratava de um moleque. O narrador, então, se posiciona:

a voz era sumida; quase um sussurro. Permaneci na mesma posição em que me encontrava, frente ao mar, absorvido com ridículas lembranças.

O importuno pedinte insistia:

- Moço, Oh! moço! Moço, me dá um cigarro?

- Vá embora, moleque, senão chamo a polícia.

- Está bem, moço. Não se zangue. E, por favor, saia da minha frente, que eu também gosto de ver o mar (RUBIÃO, 2005, p. 143).

A voz, os modos, como se pode perceber, são servis, mas sem deixar de marcar sua posição, como um ser que deve e merece respeito. 0 "moleque" gostar de ver o mar e querer um cigarro são indícios de sua humanidade. Nesse iniciozinho da narrativa não se sabe a natureza do ser que solicita o cigarro, ainda que se reconheça o desconhecimento entre ele e o narrador. Sobre isso ele relata: 
Exasperou-me a insolência de quem assim me tratava e virei-me, disposto a escorraçá-lo com um pontapé. Fui desarmado, entretanto. Diante de mim estava um coelhinho cinzento, a me interpelar delicadamente:

- Você não dá é porque não tem, não é, moço?

O seu jeito polido de dizer as coisas comoveu-me (RUBIÃO, 2005, p. 143).

Como observa Rosenfeld, em "Literatura e personagem" (2011, p. 1149), acerca da construção da personagem na narrativa de ficção, há a necessidade da presença do elemento humano para que a narrativa se constitua e, a partir disso, podemos observar o caráter antropomórfico da personagem de Rubião. O "coelhinho cinzento" capaz de comover pelo seu jeito polido de pedir um cigarro é o aparente moleque, que em seguida demonstra sua aptidão para a metamorfose. O conto rubiano vai gradativamente desestruturando as formas clássicas, principalmente ao construir um coelho falante, que rompe com qualquer expectativa ao pedir um cigarro em uma praia, na rua.

Todavia, é o "coelho cinzento", a personagem que, tal qual o conhecido Pinóquio (COLLODI, 2005), almeja ser um homem. É sabido que o boneco feito de carvalho era capaz de grandes façanhas para tornar-se menino (COLLODI, 2005), de mesmo modo o coelhinho humanizado pouco a pouco planeja sua ascensão a homem, o único problema é que suas mudanças não obedecem aos seus desejos, ele consegue se modificar como quer, porém ser homem não ocorre como se pode constatar, no decorrer da narrativa, deixando para ser menino, a contra gosto, apenas na hora da morte.

As metamorfoses de Teleco, ou Barbosa, são contínuas e parte de sua constituição. O coelhinho, apresentado ao leitor por meio de um pedido, instaura o insólito devido às suas mudanças ininterruptas, sendo também um ser inaudito, pois a naturalidade de sua fala não é comum, ordinária, para o senso-comum vigente. No âmbito narrativo não há indícios de estranhamento ou mesmo dúvidas em relação à condição da personagem, ao contrário, o narrador convida-o para dividir seu lar, como revela em:

Ao fim da tarde, indaguei onde ele morava. Disse não ter morada certa. A rua era o seu pouso habitual. Foi nesse momento que reparei nos seus olhos. Olhos mansos e tristes. Deles me apiedei e convidei-o a residir comigo. A casa era grande e morava sozinho - acrescentei.

A explicação não o convenceu. Exigiu-me que revelasse minhas reais intenções:

- Por acaso, o senhor gosta de carne de coelho?

Não esperou pela resposta:

- Se gosta, pode procurar outro, porque a versatilidade é o meu fraco. 
Dizendo isto, transformou-se numa girafa.

- À noite - prosseguiu - serei cobra ou pombo. Não lhe importará a companhia de alguém tão instável?

Respondi-Ihe que não e fomos morar juntos (RUBIÃO, 2005, p. 144 - grifos nossos).

O coelhinho insólito não se importa de ser acolhido por um completo estranho, ao contrário, seu incômodo está relacionado à recepção do outro, temendo que este não goste de sua companhia, afinal, instável e versátil. $\mathrm{O}$ narrador apiedou-se do olhar de Teleco, porém o convite repentino e inesperado rompe com a normalidade da narrativa, já que nem mesmo Teleco entende o convite, por outro lado, a rápida aceitação do convite permite que haja uma ordenação daquela realidade. Assim, depreende-se que, se- guindo as acepções descritas por Bella Josef, em A máscara e o enigma (2006), o fantástico nutre-se do absurdo, formulando realidades multiface- tadas, em que não há espanto, nem dúvidas, apenas uma exacerbação da manifestação do insólito, até o ponto em que o insólito pareça sólito no âmbito da linguagem em uma realidade aparentemente destorcida, "não somos lançados ao caos mas a uma especial ordenação do caos, que é a do autor" (COVIZZI, 1978, p. 31). Nas palavras deJosef:

a literatura fantástica apresenta uma ambiguidade nas relações entre o indivíduo e a realidade, isto é, as coisas que estão à sua volta. Reconhece o escritor o absurdo do mundo, falando, assim, sua própria linguagem - a do absurdo. Há um desdobramento do real ou sua multiplicação em formas que o negam como tal, na lógica do ilógico. O impossível e o não-comprovado são vividos, ainda que através do absurdo, há o desenrolar de situações inusitadas como as mais comuns (2006, p. 202 - grifosnossos).

Não é sólito as personagens se encontrarem repentinamente e se entregarem a uma relação de amizade, de compartilhamento, contudo, o narrador convida Teleco a dividir seu apartamento vazio, solitário. As situações inusitadas vão se acumulando, o que aparenta ser lógico gera gradativamente rupturas, como se pode ver nos argumentos do coelhinho ao ser convidado para morar com o narrador. Seria coerente, seguindo a lógica narrativa, que o coelho se sentisse acolhido pelo convite do narrador, mas a preocupação dele é não tornar a convivência insuportável pela inconstância de suas metamorfoses.

Logo, as metamorfoses, como são mencionadas, apesar de voluntárias, trariam a Barbosa, de certo modo, o mesmo mal-estar gerado em Gregor ao constatar sua animalização. Em ambas as personagens há o desejo 
de estar na forma humana, porém suas vontades confrontam-se com a continuidade de suas condições insólitas. Na narrativa rubiana, o caos, instalado pelas metamorfoses, promove a manutenção da ruptura pela contínua presença do animal, que almeja ser homem, sem se esquecer de pôr em evidência a busca da personagem pela transformação que o fará sair de seu estado animal.

Nesse sentido, a narrativa promove um debate frente à própria constituição de Teleco, que cede espaço para que outro conte sua história, um narrador aparentemente comum, corriqueiro, mas que se compadece de um olhar "infeliz" na praia. Será? É mesmo o narrador uma personagem qualquer que conta a narrativa de Teleco, o coelhinho capaz de metamor-foses? Não, o narrador é alguém envolvido no plano das ações, já que, em momento seguinte, cobiça Tereza, a amada de Teleco. O primeiro convite à convivência ocasiona estranhamento e mesmo desconfiança, até mesmo revelado por Teleco, que ao aceitar e dar prosseguimento a vida é vítima da inveja daquele que outrora parecia ter tudo. Se não bastassem os inconve- nientes das constantes metamorfoses, Teleco ainda corrompe-se devido ao desejo derradeiro, tornar-se um homem a qualquer custo, sendo mesmo vítima da inveja de seu único amigo.

O insólito instaura-se a partir do caos, da relação entre homem e coeIho, que decidem compartilhar suas vidas, sem perder de vista as implicações envolvidas nessa amizade. Os amigos decidirem morar juntos, o que parece normal é pano de fundo de um encontro inesperado, mas que desencadeia toda uma rede de relações e confrontações também inusuais.Como destaca o narrador:

\footnotetext{
depois de uma convivência maior, descobri que a mania de metamorfosearse em outros bichos era nele simples desejo de agradar ao próximo. Gostava de ser gentil com crianças e velhos, divertindo-os com hábeis malabarismos ou prestando-Ihes ajuda. O mesmo cavalo, que, pela manhã, galopava com a gurizada, à tardinha, em lento caminhar, conduzia anciãos ou inválidos às suas casas (RUBIÃO, 2005, p. 144-145).
}

Não se pode negar que Teleco seja uma personagem bastante amigável e acessível, que, porém, oscila entre universos de sentido. Ele é teimoso e arredio, ao relacionar-se com o narrador devido aos ciúmes de Tereza - marca não evidente na narrativa, o único indício do conflito é o desconforto de ambos após Teleco tornar-se Barbosa e introduzir Tereza em sua relação com o narrador, ocasionando mal-estar e sua consequente expulsão -, mas capaz de inúmeras façanhas para entreter os amigos e 
pessoas que o cercavam. A personagem ganha relevo na voz de um narrador envolvido, diretamente, nas ações, sendo dono do lugar onde moram e, de certo modo, provedor, afinal, o coelho começa a ganhar destaque ao tornar-se um mágico. Dessa maneira, o cenário em que convivem o narrador, Barbosa e Tereza seria um espaço comume poder-se-ia considerá-lo prosaico pelo caráter urbano das cenas, que dentre outras coisas envolve a reclamação dos vizinhos, os quais, vítimas das constantes mudanças, "não entendiam e se queixavam à polícia" (RUBIÃO, 2005, p. 145).

De acordo com o narrador, Teleco não fazia mal a ninguém, se metamorfoseava por gênio e mesmo por brincadeira, ele "assustava-os mais para nos divertir que por maldade" (RUBIÃO, 2005, p. 145). A voz do narrador isenta o coelho da malícia e da agressão, evidenciando-o como um ser humano capaz de intempéries e também implicâncias. Contudo, "as metamorfoses [...] acontecem seja como forma de Teleco demonstrar seus poderes, seja por absoluta falta de controle dos mesmos poderes" (GAMAKHALIL, 2013, p. 54). Fato é que enfrentando os vizinhos e a polícia, a quem esses se queixavam, Teleco vai afinando sua convivência com o narrador, o amigo encontrado na praia, quando ambos olhavam o mar.

As relações insólitas que são estabelecidas na narrativa permitem o questionamento acerca da constituição do próprio texto, pois Rubião ambienta a narrativa na cidade, tendo como primeiro contato o encontro inesperado em uma praia, em um segundo momento, o autor elabora uma personagem deslocada da sociedade, um ser à margem, confrontado pelo seu eu insólito, estar transformado em coelhinho. Em seguida, o leitor já afrontado pelas situações inusitadas, como já se observou, depara-se com o grande e contínuo "sonho" de Teleco que é ser homem, portanto, inserir-se na sociedade. Como revela Marisa Martins Gama-Khalil (2013, p. 48):

O que a literatura fantástica faz é tematizar essa modificações que permeiam a subjetividade do sujeito e fazem com que ele, a cada momento, se torne diferente. Essa tematização da metamorfose se dá, então, pelas vias do "eu", por um processo de subjetivação advindos de fatores externos e internos.

A subjetivação de Teleco se concretiza nas constantes metamorfoses que, em certo sentido, caracterizam-no como um ser múltiplo, em constante variabilidade, ainda que com uma única aspiração. O fantástico instaurado na realidade constrói-se pela via da ruptura, permitindo que se leiam os confrontos e atitudes das personagens através da configuração do insólito presente também na própria linguagem, em que os vazios e anacronismos 
deixam margem para interpretações conflituosas e ancoradas na ruptura do próprio caos instalado. Diante de uma personagem elaborada à margem, "lutando" pela humanização, o narrador almeja apenas rever o coelhinho cinzento e meigo, sem levar em consideração as vontades do amigo. Como se pode notar, Tereza, namorada de Teleco, tornou-se fruto do amor do narrador, que observa:

\begin{abstract}
durante a noite, na qual me faltou o sono, meus pensamentos giravam em torno dela e da cretinice de Teleco em afirmar-se homem.

Levantei-me de madrugada e me dirigi à sala, na expectativa de que os fatos do dia anterior não passassem de mais um doa gracejos do meu companheiro. Enganava-me. Deitado ao lado da moça, no tapete do assoalho, o canguru ressonava alto (RUBIÃO, 2005, p. 147).
\end{abstract}

Para esse narrador, aparentemente, interessavam os amores do coeIho, um olhar afetuoso que fosse de Tereza, correspondendo seu amor por ela e desprezo por Barbosa.Ele considerava a atitude de Teleco, querer ser homem, ainda que metamorfoseado em canguru, como uma trapaça, destituindo o outrora amigo de seu papel, apenas porque esse não queria mais continuar a modificar-se. A amizade inesperada é minada pela repentina paixão do narrador pela namorada de Teleco, indicando ciúme devido às novas relações que se estabeleceram, como também um desejo de manterse no comando, já que homem em oposição à condição animal do outro.

\title{
2 O INDIVÍDUO: TELECO E/OU BARBOSA
}

era o amigo dócil, que nos encantava com inesperadas mágicas. Amava as cores e muitas vezes surgia transmutado em ave que as possuía todas e de espécie inteiramente desconhecida ou de raça já extinta (RUBIÃO, 2005, p. 146).

Nesse sentido, percebe-se que a mudança para esse ser não é só necessária, como também uma experiência essencial. O "coelho" rubiano molda-se a partir da mudança, do vazio, que se gera pela ausência da "verdadeira" transformação, pois o coelho modifica-se invariavelmente, menos no que almejava ser:

- Eu sou Teleco - antecipou-se, dando uma risadinha.

Mirei com desprezo aquele bicho mesquinho, de pêlos ralos, a denunciar subserviência e torpeza. Nada nele me fazia lembrar o travesso coelhinho.

Neguei-me a aceitar como verdadeira a afirmação, pois Teleco não sofria da vista e se quisesse apresentar-se vestido teria o bom gosto de escolher outros trajes que não aqueles. 
Ante a minha incredulidade, transformou-se numa perereca. [...]

Retornando a forma de canguru, inquiriu-me, com um ar extremamente grave:

- Basta esta prova?

- Basta. E daí? O que você quer?

- De hoje em diante serei apenas homem.

- Homem? - indaguei atônito. Não resisti ao ridículo da situação e dei uma gargalhada:

- E isso? - apontei para a mulher. - É uma lagartixa ou um filhote de salamandra?

Ela me olhou com raiva. Quis retrucar, porém ele atalhou:

- É Tereza. Veio morar conosco. Não é linda? (RUBIÃO, 2005, p. 147).

Primeiro ele era um coelho atrás de um simples cigarro, depois o canguru que queria ser homem, Teleco/Barbosa invariavelmente traz em si marcas do fantástico, chegando mesmo, devido às metamorfoses e a dupla constituição, a tocar a temática do duplo, sendo um "eu", não-social e meigo, e "outro", social e áspero. Pode parecer estranho um coelho pedir um simples cigarro, mas é exatamente essa antropomorfização vinculada à necessidade de adequação, com uma perspectiva, é óbvio, própria do homem citadino contemporâneo - o desejar serintimamente ligado a buscas da sociedade atual - , que denuncia a consciência da diferença, demonstrada pelo fato de o coelho querer tornar-se humano. De acordo com Birman (2012, p. 141), em "Do sofrimento à dor", a subjetividade contemporânea, imersa na dor do ressentimento, "se evidencia como essencialmente narcísica, não se abrindo para o outro, de quem em princípio desconfia e rivaliza".

A personagem Teleco e o narrador, ambos, rivalizam e sentem-se confrontados, enquanto Teleco era coelho não havia conflito, porém ao querer tornar-se Barbosa desafia a dor do outro, o narrador. Assim, Teleco/Barbosa e o narrador dividem-se devido ao individualismo, que acaba fazendo-os desejar as mesmas coisas, até mulher do metamorfoseado. A individualização, a ponto de brigarem, torna-se mais evidente pela súbita relação anteriormente formada, os amigos da praia começam a discutir por qualquer motivo. Se não bastassem os confrontos, o narrador reitera a todo o momento que Barbosa não era o seu amigo, o coelhinho meigo que conhecera na praia sim.

Será que existiam duas personagens realmente? O canguru, que queria ser homem, Antônio Barbosa e Teleco, o coelhinho com jeito moleque, eram dois em um ou um em dois? A narrativa em momento algum denun- 
cia uma duplicidade da configuração dessas personagens, Teleconão se duplica, apenas se metamorfoseia, porém suas marcas constitutivas ao virar Barbosa são, segundo o narrador, completamente distintas do coelhinho de antes. Como se pode perceber, o coelho abandona sua outra identidade, aspirando tornarsua nova condição duradoura:

- Teleco?! Meu nome é Barbosa, Antônio Barbosa, não é Tereza?

Ela, que acabara de despertar, assentiu, movendo a cabeça.

Explodi, encolerizado:

- Se é Barbosa, rua! E não me ponha mais os pés aqui, filho de um rato!

Desceram-Ihe as lágrimas pelo rosto e, ajoelhado, na minha frente, acariciava

minhas pernas, pedindo-me que não o expulsasse de casa, pelo menos enquanto procurava emprego.

Embora encarasse com ceticismo a possibilidade de empregar-se um canguru [...] fui persuadido pelo olhar súplice e Tereza que, apreensiva, acompanhava o nosso diálogo (RUBIÃO, 2005, p. 148).

O coelho já não existia mais, a não ser por meio das súplicas, da so- bra de seu outro eu. A nova condição da personagem transformada em Barbosa evoca a manifestação do insólito também no âmbito da consciên- cia, já que nem narrador, nem personagem aceitam pacificamente a mu- dança, o primeiro pretende que seu amigo retorne, o coelhinho Teleco, enquanto o segundo espera o próximo passo de sua transformação, tornar- se homem.Conforme Jackson (apud CESERANI, 2006, p. 84 - grifos do au- tor),

As subjetividades parciais ou desmembradas rompem uma prática de significação "realista" que representa o ego como uma unidade indivisível. As fantasias procuram inverter ou interromper o processo de formação do ego que se realizou durante o estágio de desenvolvimento, isto é, procuram adentrar no imaginário. Dualismo e desmembramento são sintomas desse desejo do imaginário.

Logo, nota-se que o desejo do imaginário ganha espaço, por isso, o velho coelho já nãoestava mais ali, existia sim um "outro" metamorfoseado não apenas em Barbosa, o canguru, mas principalmente na sua crença em ser homem. O narrador, por sua vez, determinado a expulsar esse estranho de sua vida, cobiça mesmo a mulher de seu melhor amigo, confundindo o outro e confundido pelo outro. $O$ desprezo por Barbosa fica bem evidente quando ele narra:

Talvez por ter-me abandonado aos encantos de Tereza, ou para não desagradá-la, o certo é que aceitava, sem protesto, a presença incômoda de Barbosa. 
Se afirmava ser tolice de Teleco querer nos impor sua falsa condição humana, ela me respondia com uma convicção desconcertante:

- Ele se chama Barbosa e é um homem.

O canguru percebeu o meu interesse pela sua companheira e, confundindo a minha tolerância como possível fraqueza, tornou-se atrevido e zombava de mim quando o recriminava por vestir minhas roupas, fumar dos meus cigarros ou subtrair dinheiro do meu bolso.

Em diversas ocasiões, apelei para a sua frouxa sensibilidade, pedindo-Ihe que voltasse a ser coelho.

- Voltar a ser coelho? Nunca fui bicho. Nem sei de quem você fala.

- Falo de um coelhinho cinzento e meigo, que costumava se transformar em outros animais (RUBIÃO, 2005, p. 149 - grifos nossos).

Desse modo, percebe-se a tentativa de Teleco em se auto-afirmar, lutando contra sua condição não humana. A namorada Tereza, sem aceitar as investidas do amigo, também reconhece Teleco/Batista como homem, dotada, para tanto, como afirma o narrador, de uma "convicção desconcertante". No entanto, se distanciando do seu eu anterior, Teleco não era mais o "coelhinho meigo e cinzento", ao contrário, "tinha hábitos horríveis" (RUBIÃO, 2005, p.148), chegando mesmo a subtrair dinheiro do bolso do narrador.

Com isso, observa-se que o estar no mundo de Teleco, em forma de coelho, deixa-o apartado da convivência social, pois animalizado e, se não bastasse, era o coelhinho digno de pena. Contudo, deixar de ser coelho para tornar-se homem não o faz um ser mais humano, ele revela-se como um homem menos civilizado do que quando estava na forma de animal. As metamorfoses geram na personagem uma fragilidade, não apenas física, mas psíquica, visto que continuamente precisa se afirmar, lutando pelo "título" de homem, o qual era, em geral, ironizado pelo narrador.

A partir desse olhar sobre os conflitos internos a personagem, que geram uma instauração gradativa do caos, o qual só é reordenado pelo desfecho fatal, depreende-se que essa categoria narrativa, a personagem, como eixo em torno do qual gira a ação (REIS, 2001, p. 360). No conto de Murilo Rubião, a personagem é identificada pelo nome, tendo o narrador como confidente, até que esse também começa a atuar, comonarradorpersonagem, dividindo com Teleco os cenários e as intempéries de sua vida. A respeito dos componentes narrativos, Carlos Reis (2001, p. 361) diz: "a personagem constitui o agente de acções variavelmente complexas".

O coelhinho Teleco é uma personagem de consciência insólita, pois capaz de inúmeras metamorfoses, vivendo entre outros e a eles afrontando 
mesmo pelo mal-estar gerado pelo inexplicado de sua vida.As metamorfoses chegam sem querer e tornam-no outro, por vezes ele almeja isso, como é revelado, mas em outros momentos as metamorfoses irrompem a contragosto e, caso se possa afirmar isso, de modo insólito atrapalham a sua vida.Observa-se, assim, que Teleco e o narrador são agentes das discussões em torno do conto rubiano, uma vez que se cruzam aleatoriamente e a convivência desencadeia uma série de acontecimentos derivados do desejo do narrador em revelar a história de "Teleco, o coelhinho".

A briga, que desencadeou todos os problemas de Teleco, foi gerada pela sua metamorfose em canguru, e consequente convivência com Tereza. O narrador, amigável outrora, acabou levado pela cobiça, por um desejo, o qual o fez perder o amigo e ver partir a mulher que amava, chegando mesmo a revelar que "foi a última vez que os vi" (RUBIÃO, 2005, p. 150). Entretanto, a paixão dos últimos tempos aparenta manter-se nos interiores dessa personagem, que repentinamente para de contar as histórias de Teleco para narrar suas angústias, seus ressentimentos em relação àquele que fora seu amigo.

O repentino amor, iniciado ao ver Tereza ao lado de Barbosa, pouco a pouco cede espaço para uma lembrança, e o narrador revela "a minha paixão por Tereza se esfumara no tempo e voltara-me o interesse pelos selos" (RUBIÃO, 2005, p. 150). Assim, percebe-se a fugacidade das relações humanas passíveis de serem substituídas por um interesse em selos. A questão que resta, devido ao desencadeamento narrativo, gira em torno do destino e futuro desse coelho que queria ser homem. Entretanto, as notícias narra- das não tornam perceptível o que acontecera ao "canguru", segundo o nar- rador ele teria virado um mágico de sucesso. Consequentemente, a condi- ção de Teleco havia mudado, pois um mágico de sucesso não tem o mesmo patamar de um coelhinho tristonho. Assim, percebe-se que mesmo na rea- lização dos sonhos e na concretização de situações a irrupção do insólito se mantém e as personagens continuam a tentar estabelecer a normalidade dentro de uma realidade completamente alucinada.

A vida de todos parecia conformada e ajustada, até que repentinamente:

- Sou o Teleco, seu amigo - afirmou, com uma voz excessivamente trêmula e triste, transformando-se em uma cotia.

- E ela? - perguntei com simulada displicência.

- Tereza... - sem que concluísse a frase, adquiriu as formas de um pavão.

- Havia muitas cores... o circo... ela estava linda... foi horrível...prosseguiu, chocalhando os guizos de uma cascavel. 
Seguiu-se breve silêncio, antes que voltasse a falar:

- O uniforme... muito branco... cinco cordas... amanhã serei homem... - as palavras saíam-lhe espremidas, sem nexo, à medida que Teleco se metamorfoseava em outros animais (RUBIÃO, 2005, p. 151).

$\mathrm{O}$ amigo volta a surgir diante do narrador, o canguru que ele odiava deixou-se metamorfosear, porém, ao contrário do que ocorria anteriormente, Teleco já não controlava em nenhum sentido ou forma suas mudanças, demonstrando o sofrimento por meio das "palavras que Ihe saíam espremidas".O tempo longe parece que fez perecerem os talentos do "mágico" coelhinho, agora necessitando novamente do auxilio e cuidados do narrador. $O$ encontro volta a acontecer repentinamente, e marcado pela mudança de Teleco, que agonizava pelas metamorfoses, as quais não o deixavam mais.O narrador, assim, observa"na última noite, apenas estremecia de leve e, aos poucos, se aquietou. Cansado pela longa vigília, cerrei os olhos e adormeci. Ao acordar, percebi que uma coisa se transformara nos meus braços. No meu colo estava uma criança encardida, sem dentes. Morta" (RUBIÃO, 2005, p. 152).

Finalmente, Teleco tornava-se homem e, do mesmo modo que Gregor, deixara a dor e o sofrimento. Na contramão do ocorrido com Pinóquio, a vida não mais o habitava, sem mudanças aparentemente as forças do corpo também deixariam de existir. $O$ bonequinho queria ganhar vida e tornar-se menino, já Teleco passara sua vida tentando ser homem, mas é a morte que Ihe garante sua última e verdadeira humanidade. Afinal, em todo o tempo anterior Teleco queria ser Barbosa, mas sua natureza era a de um canguru mal-educado.

\section{CONCLUSÃO}

O homem 'normal' é precisamenteo ser fantbstico; o fantbstico torna-se a regra, não a exceção (TODOROV, 2010, p. 181).

O coelho Teleco é precisamente o ser fantástico, corroborando a condição insólita de seu amigo narrador, alguém que, contrariando as expectativas, brinca com as relações ao ir e vir no campo da diegese, conjugando em si a bondade do amigo acolhedor e a maldade do homem desafiado. Assim, as personagens, que desencadeiam todas as ações da narrativa, são seres insólitos, alijados de uma construção pautada pelo que é tido como lógico pelo senso-comum. Elas formam-se por relações humanas 
estranhas e estranhadas por si mesmas, já que o coelho temia virar comida, enfatizando a desconfiança diante da bondade do outro.

O narrador, por sua vez, ao confrontar-se com Barbosa, o outro "eu" de Teleco, sente-se traído, como se o maior desejo do coelhinho the causasse angústias e mesmo revolta. Os conflitos não cessam a as leituras para o mundo em torno de "Teleco, o coelhinho" sãi infindáveis, visto que os homens perdem-se em suas próprias vidas, o narrador cobiça as conquistas do amigo, mas não tem história aparente, vivendo da companhia desse outro, que ele pretende manter animalizado.

Dessa forma, depreende-se um conflito interno entre as personagens, que sofrem a dor de viver, confrontadas pela transformação que é e está na própria realidade. Nada na vida é estático e fixo, no caso de Teleco nem mesmo as formas de seu corpo. A narrativa rubiana deixa antever a capacidade da mudança e o poder do sonho, porém a morte inadvertidamente rompe com a ordem caótica instaurada e aquele que parecia fadado ao eterno desejo de tornar-se homem vira um menino de aparência estranha. Com isso, a exceção torna-se regra e a lógica do ilógico manifesta-se e permanece no decorrer da narrativa, se outrora o herói era normal, aqui ele é um coelho diferente e claramente fantástico (TODOROV, 2010, p. 182).

\section{REFERÊNCIAS}

BIRMAN, Joel. Do sofrimento à dor. In: O sujeito na contemporaneidade: espaço, dor e desalento na atualidade. Rio de Janeiro: Civ. Brasileira, 2012, p. 137-144.

CALVINO, Italo. Introdução. In: CALVINO, Italo. (Org.). Contos fantásticos do séc. XIX: o fantástico visionário e o fantástico cotidiano. São Paulo: Cia. das Letras, 2004, p. 9-18.

CESERANI, Remo. Procedimentos formais e sistemas temáticos do fantástico. In: O fantástico. Curitiba: EdUFPR, 2006, p. 67-88.

COLLODI, Carlos. Pinóquio. Porto Alegre: L\&PM Pocket, 2005.

COVIZZI, Lenira Marques. O insólito em Guimarães Rosa e Borges. São Paulo: Ática, 1978.

ECO, Umberto. Seis passeios pelos bosques da ficção. São Paulo: Cia. das Letras, 1994.

GAMA-KHALIL, Marisa Martins. As metamorfoses do corpo e a construção do fantástico nas narrativas de Murilo Rubião. In: GARCÍA, Flavio; BATALHA, Maria Cristina. (Org.). Murilo Rubião 20 anos depois e sua morte. Rio de Janeiro: EdUERJ, 2013, p. 47-66. 
JOZEF, Bella. A máscara e o enigma. A modernidade: da representação à transgressão. Rio de Janeiro: F. Alves, 2006.

KAFKA, Franz. A metamorfose. São Paulo: Cia. das Letras, 1997.

REIS, Carlos. A narrativa literária. In: O conhecimento da literatura. Introdu-ção aos estudos literários. 2. ed. Coimbra: Almedina, 2001, p. 343-377.

ROAS, David. Tras los límites de lo real. Uma definición de lo fantástico. Madrid: Páginas de Espuma, 2011.

ROSENFELD, Anatol. Literatura e personagem. In: CANDIDO, Antonio et al. $A$ personagem de fiç̧ão. 12. ed. São Paulo: Perspectiva, 2011, p. 11-49.

RUBIÃO, Murilo. Teleco, o coelhinho. In: Murilo Rubião: contos reunidos. São Paulo: Ática, 2005, p. 143-152.

TODOROV, Tzvetan. Literatura e fantástico. In: Introdução à literatura fantástica. 4. ed. São Paulo: Perspectiva, 2010, p. 165-183. 